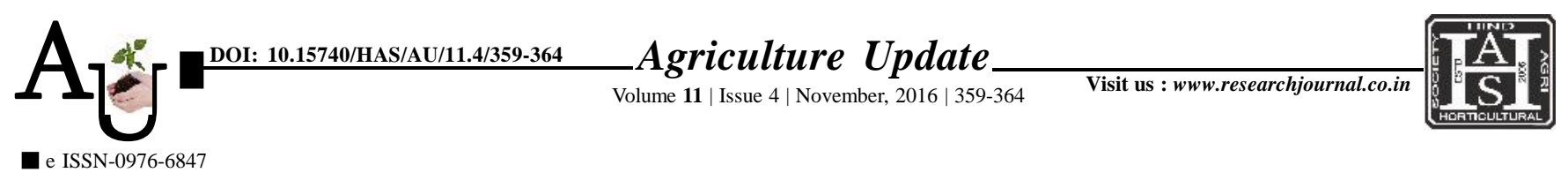

\title{
Research Article: Correlates of training needs and constraints faced by the sugarcane growers
}

\section{G. K. WAMAN, B. A. MANIKDURGE AND P. B. KHARDE}

Article Chronicle: Received :

11.02.2016;

Revised :

17.09.2016;

Accepted :

03.10.2016

\section{KeY WoRds:}

Sugarcane

production

technology,

Knowledge,

Training needs,

Constraints,

Suggestions

Author for correspondence :

\section{G.K. WAMAN}

Directorate of Extension Education, Mahatma Phule Krishi Vidyapeeth, Rahuri, AHMEDNAGAR (M.S.) INDIA

See end of the article for authors' affiliations
SUMMARY : The present investigation was carried out in Rahuri and Karjat tahsils of Ahmednagar districts (M.S.). The results of study revealed that majority of the sugarcane growers had medium to high level of knowledge about sugarcane production technology. A majority of them had partial knowledge about pest and disease management followed by the intercultural operation, recommended varieties, fertilizer management, irrigation management and soil testing. The respondents' characteristics viz., age, education, annual income and social participation had negative and significant relationship with their training needs at 5 per cent level of significance. Size of land holding and knowledge of the sugarcane growers showed positive and significant relationship with the training needs. Training on biological pest control, availability of fertilizers and crop loan in cheaper rate were some of suggestions made by the sugarcane growers.

How to cite this article : Waman, G. K., Manikdurge, B. A. and Kharde, P. B. (2016). Correlates of training needs and constraints faced by the sugarcane growers. Agric. Update, 11(4): 359-364; DOI : 10.15740/HAS/AU/11.4/ 359-364. 